International Journal of Life Sciences
Available online at www.Sciencescholar.us
Vol. 4 No. 3 December 2020, pages: 16-30
e-ISSN: 2550-6986, p-ISSN: 2550-6994
https://doi.org/10.29332/ijls.v4n3.472

\title{
The Independence Level of Farmers in Subak Abian Tri Guna Karya on Processing and Marketing Agricultural Products
}

\author{
Ni Ketut Karyatia, Wayan Windia ${ }^{b}$, Budi Susrusac, Gede Setiawan Adiputrad
}

Manuscript submitted: 09 September 2020, Manuscript revised: 27 October 2020, Accepted for publication: 18 November 2020

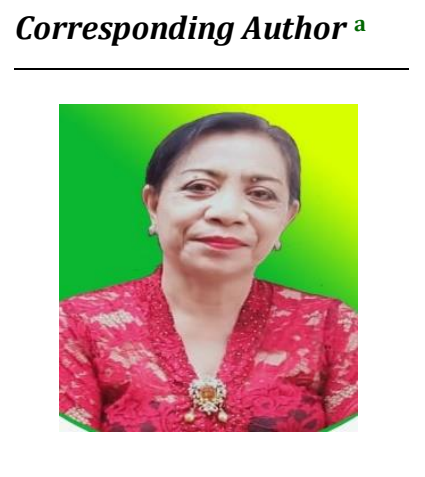

\section{Keywords}

agricultural;

farmers independence;

marketing;

processing;

products;

\begin{abstract}
Poverty in Indonesia is a very complex and multidimensional problem relating to political, economic, social, and cultural aspects. Most of the families who depend on agricultural products are poor. Even though the role of agriculture in the country's economic development is still very important. Approximately $60 \%$ of the population still working in agriculture or still depending on agricultural products for their living. This study aimed to analyze the level of independence of farmers in marketing and processing agricultural products. The research method used includes qualitative and quantitative data types, data sources were primary and secondary data. The population observed was 77 people. The data analysis technique used descriptive analysis and statistical analysis with PLS (Partial Least Square) method. Based on the results of the analysis and discussion, it can be concluded that farmers of Subak Abian Tri Guna Karya, Kintamani District, Bangli Regency have a good independence level in terms of economy, intellectual, and emotional in processing and marketing their agricultural products.
\end{abstract}

International Journal of Life Sciences (C) 2020. This is an open access article under the CC BY-NC-ND license (https://creativecommons.org/licenses/by-nc-nd/4.0/).

\section{Contents}

Abstract

1 Introduction.

Materials and Method

Results and Discussions

3.2 Independence level of Subak Abian Tri Guna Karya Farmers, Kintamani District, Bangli Regency in processing and marketing of products

\footnotetext{
a Student of Doctoral Program of Agricultural Science, University of Udayana, Denpasar, Indonesia

b Lecturer of Agricultural Science Doctoral Program, University of Udayana, Denpasar, Indonesia

c Lecturer of Agricultural Science Doctoral Program, University of Udayana, Denpasar, Indonesia

${ }^{d}$ Lecturer of Agricultural Science Doctoral Program, University of Udayana, Denpasar, Indonesia
} 
3.3 Discussion on the level of farmers independence in Subak Abian Tri Guna Karya, Kintamani District, Bangli Regency in processing and marketing of agricultural products.

4 Conclusion

Acknowledgments..

References...

\section{Introduction}

The problem of poverty in Indonesia is very complex and multidimensional relating to political, economic, social, and cultural aspects. The main priority in development to improve welfare and economic growth is to overcome the problem of poverty, although it has not been fully resolved, these efforts continue to be made, without neglecting economic growth (Permana \& Purnomo, 2014). Indonesia is as an agricultural country, was able to contribute $25.74 \%$ to the National GDP in 2011 (Elina et al., 2012). Labor absorption reached $41 \%$ (Agricultural Sector GDP Bulletin, 2004). The role of agriculture in the country's economic development is still very important, although the increasing role every year is not optimal; its role in contributing to state revenue in the Gross Domestic Product is approximately 23\%. Also, approximately $60 \%$ of the population is still doing business in agriculture or is still depending on agricultural products (Elina et al., 2012).

The problem of agricultural development lies not only in its technological devices but also in its institutional structure (Sinaga \& White, 1980). The institutional aspect still plays an important role in agricultural development, so that efforts are needed to strengthen farmers by empowering them through collective farming (Mubyarto, 1994). Empowerment in the community is a very important strength, whether seen from the physical, material, economic, and income aspects, institutions (the growth of individual strength in the form of organization/group), the strength of cooperation, intellectual strength, and the strength of collective commitment to comply with and apply the principles of empowerment. The importance of community empowerment is to create independence so that people can act, understand, and apply it in various development activities (Sunyoto, 2004).

Community empowerment which is characterized by independence can be achieved through the community empowerment process (Sumodiningrat, 1999). The implementation of this program was aimed at empowering local villagers to improve their socio-economic and environmental conditions independently / sustainably (Suhartini et al., 2005).

Human development is essentially a development that aims to improve self-quality, which includes insight and knowledge, mental attitudes, and skills that are optimally developed to achieve individual and community independence (Sulistyani, 2004). Community independence is a condition experienced by the community to think, decide and do something that is deemed appropriate to achieve problem-solving faced by using cognitive, affective, psychomotor abilities, by mobilizing human resources owned by the internal environment of the community (Sulistyani, 2004). In community empowerment, the dimensions of social capital must be included as one of its components, because social capital which contains trust, networks, and social norms, as well as ethical values, is the supporting foundation that will determine the development and sustainability of various business activities in various sectors of life (Mawardi, 2007).

The results of studies in various countries showed that strong social capital will stimulate economic growth due to a high level of trust and close relationships in a wider network among economic actors (Fukuyama \& Amrullah, 1999). Social capital is a new resource that can be viewed as an investment to obtain new resources. A resource is something that can be used for consumption, storage, and investment. Social capital is seen as an important ingredient for the development of community economic empowerment (Mawardi, 2007). The independence of farmer group members by strengthening financial capital can be achieved if it is accompanied by strengthening social capital in the farming community (Schaller, 1993; Sharpley et al., 1999; Molden et al., 2010). Strengthening social capital in rural development can be seen as a very important renewal of the approach, and can be seen as very positive energy for the development of community economic empowerment (Pranadji, 2017).

The Provincial Government of Bali in collaboration with Bali Regional Development Bank (BPD), starting in 2008, has launched Capital Business Strengthening Program (PMU) community for Subak Abian (SU),

Karyati, N. K. ., Windia, W. ., Susrusa, B. ., \& Adiputra, G. S. . (2020). The independence level of farmers in Subak Abian Tri Guna Karya on processing and marketing agricultural products. International Journal of Life Sciences, 4(3), 16-30. https://doi.org/10.29332/ijls.v4n3.472 
productive business units (UUP), and productive business cooperatives, to increase community capital business, improve the quality of processing and marketing products, increase employment opportunities that can increase the productivity, income, and welfare of farmers towards "independent" farmers. From 2007 to 2011 the total funds have been allocated by the Bali Provincial Government to assist farmers in strengthening Subak Abian / UUP / UKP business capital through APBD was Rp. 13 billion. The distribution of credit to strengthen capital business, especially for processing and marketing of agricultural products is carried out through Bali Regional Development Bank (BPD), with 2\% interest per year decreasing with provision fee of 0, $75 \%$, plus guarantee engagement fee at the notary.

One of the groups that utilize the largest Capital Business Strengthening (PMU) fund in Bangli is Subak Abian Tri Guna Karya. This venture capital of Subak Abian will not succeed without being followed by a process of strengthening the institutional capacity of farmers. Likewise, subak will not be independent if it does not strengthen the capacity of its members. This is because capacity building is an important part of various aspects of life in everyday life (Walker \& Olson 1991; Muliarta, 2016). For example, capacity development is carried out with education, both formal and informal. A development process can't occur in any case without capacity building efforts for actors as well as the system managed. Based on this background, it was very interesting to study the independence of farmers in Subak Abian Tri Guna Karya, Kintamani District, Bangli Regency in processing and marketing agricultural products (Burger \& Cann 1995; Hutton, 1996).

\section{Literature review \\ The independence}

The term "independence" in the Indonesian language is "kemandirian" which comes from the root "diri" which gets the prefix "ke" and suffix "an", then forms a contextual word or noun. Due to "kemandirian" cannot be separated from the word "diri", then the discussion about independence or self-reliance cannot be separated from the discussion of self-development itself, which in Carl Rogers' concept is called self, because it is the essence of self-reliance or independence (Desmita, 2014).

In the theory of independence developed by Steinberg (1995), the terms independence and autonomy are often equated with interchangeable according to the concept of both terms. Although generally, both terms have the same meaning, namely independence, but as conceptually they are different. Independent generally refers to individuals' capacity to behave on their own. The independence that leads to the independence concept is a part of autonomy development during adolescence, it's just that autonomy includes emotional, behavioral, and value dimensions. Independence shows belief in one's ability to solve problems without help from others. Individuals who are independent as individuals who can solve the problems they faced can make their own decisions, have initiative, and be creative, without neglecting the environment around them. According to some experts, "independence" shows psychosocial abilities which include freedom to act, not depending on other people's abilities, not being influenced by the environment, and free to manage their own needs (Nurhayati, 2018).

\section{Types of independence}

According to Robert Havighurst, as quoted by Desmita (2014), distinguishing independence from four types of independence, namely:

1) Emotional Independence. Is the ability to control one's own emotions and does not depend on the emotional needs of others.

2) Economic Independence. Economic independence, namely the ability to regulate the self economy and not depending self economic needs of the others.

3) Intellectual Independence. Intellectual independence, namely the ability to overcome various problems at hand.

4) Social Independence. Social independence is the ability to interact with other people and not depend on others' movements. 
Characteristics of independence

Psychosocial independence is composed of three aspects, namely as follows (Nurhayati, 2018):

1) Independent of emotional is an aspect of independence that is related to the changing the approach or relationship of an individual's emotional relationship, especially with parents or other adults who have a lot of interaction with them.

2) Independent of action is the ability to make decisions freely, follow up, and be responsible.

3) Independent thinking is the freedom to interpret a set of principles about right-wrong, good-bad, and what is useful for them.

\section{Materials and Methods}

\section{Determination of data sources}

Population and Research Sample

The population or all concern observations in this research were all the farmers' members of Subak Abian Tri Guna Karya group, they were 77 people. Sampling was done through a simple random sampling technique with the consideration that all populations were homogeneous groups. The number of samples taken using Slovin theory formulation is as follows.

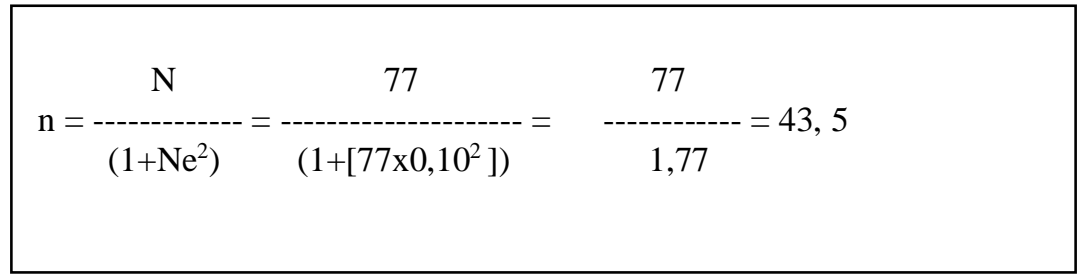

Information:

$\mathrm{n}$ = Number of samples

$\mathrm{N}=$ Total of population

c $=$ level of inaccuracy $(10 \%)$

In collecting data from farmers, data collection was also carried out from key informants who were able to provide more depth data information regarding some of the data needed to be related to the research objectives. Below were those classified into key informants of the Subak Abian management such as: the head of Subak Abian community, the Government (Agricultural Service) at the Provincial Level, the field management unit at the research location.

\section{Types and data sources}

Seen from the types and resources, the data collected in this study has consisted of primary data and secondary data. Primary data was consists of quantitative and qualitative data. Quantitative data is data in the form of numbers or qualitative data which is structured through scoring techniques. Meanwhile, qualitative data is data that cannot be elaborated through scoring techniques. The data sources of this research are divided into two, namely primary data sources obtained directly from research respondents, and secondary research data sources obtained from reports that have been written by other people and from related agencies such as the agricultural office, Subak, and other supporting publications.

Karyati, N. K. ., Windia, W. ., Susrusa, B. ., \& Adiputra, G. S. . (2020). The independence level of farmers in Subak Abian Tri Guna Karya on processing and marketing agricultural products. International Journal of Life Sciences, 4(3), 16-30. https://doi.org/10.29332/ijls.v4n3.472 
Data collection techniques

Data collection techniques are critical to the success of obtaining data that can describe the overall research observations. Therefore, the data collection techniques used in this study was: interviews, observation, and documentation study.

Data Analysis

Descriptive analysis method

Descriptive analysis is a data analysis method that use to give meaning to the data and qualitative information obtained, to describe the research phenomenon. This analysis method is used to answer the first objective, namely the types and forms of capital business strengthening programs received by Subak Abian farmers in Bangli Regency. According to Kuncoro (2007), descriptive statistics is an illustration of data using numeric and graphic methods to recognize patterns in a group of data, summarize the information in the data and present the information in the desired form.

\section{Statistical analysis techniques}

PLS (Partial Least Square) is a powerful analysis method, by it does not assume the data but must be measured at a certain scale, and with a small sample size and can also be used to confirm the theory. According to Ghozali (2011), the purpose of PLS is to help researchers for predictive purposes. The formal model defines latent variables as linear aggregates of the indicators. The weight estimate for creating latent variable score component is obtained based on how the inner model (a structural model that connects between latent variables) and the outer model (the measurement model, which is the relationship between the indicator and its construct) is specified. The reasons for using PLS in this study are as follows:

1) PLS is a general method for estimating the path model using latent variables with multiple indicators

2) PLS handles reflective and formative models, even constructs with single items (indicators) (Hair et al., 2014 in Ghozali, 2011). In this study, the analyzed structural model fulfills the recursive model and all indicators of the research variables.

PLS is an analytical method that can be applied to all data scales, does not require many assumptions and the sample size does not have to be large. The recommended sample size ranges from 30-100 cases (Ghozali, 2011). In this study, the unit of analysis was the farmer's member of subak, totaling 45 people so that it fulfilled the use of this PLS analysis.

\section{Results and Discussions}

\subsection{Research Finding Characteristics of respondents}

The characteristics of the research respondents are seen from several criteria, namely: age, gender, and educational level. The following showed the characteristics of the research respondents using these criteria.

1) Age

Based on the results of the study, an overview of the respondents was obtained which was shown in Table 4.1 below:

Table 1

Characteristics of respondents by age

\begin{tabular}{llll}
\hline No & Age & Number of respondents (people) & Percentage (\%) \\
\hline 1. & $20-25$ & 22 & $51,16 \%$ \\
2. & $26-30$ & 10 & $23,25 \%$ \\
3. & $31-35$ & 11 & $25,58 \%$ \\
& Total & 43 & $100 \%$ \\
\hline
\end{tabular}

Source: Questionnaire Collection, 2017 
Table 1 showed that the number of respondents aged 20-25 was 22 people or 51.16\%, 10 people aged 26-30 or $23.26 \%$, and 11 people aged $31-35$ or $25.58 \%$. Based on the data in Table 4.1 above, it showed that most respondents were in the age range of 20-25 years, namely $51.16 \%$. Respondents at a young age have a greater desire for getting achievement than respondents who are elderly. Young people have the creativity to develop their business and be able to keep up with technological developments, especially in nowadays, marketing skills through online media are needed so that their business continues to grow. In terms of independence, young people still need assistance because, in their daily lives, young people use their minds and thoughts emotionally rather than rationally. If you can make and create agricultural youth that creative and rational, then agricultural development will be more advanced.

2) Gender

Following the results of the study, a description of the respondents' gender was obtained which was shown in Table 2 below:

Table 2

Characteristics of Respondents Based on Gender

\begin{tabular}{llll}
\hline No & Gender & Number of respondents (people) & Percentage (\%) \\
\hline 1. & Man & 43 & $100 \%$ \\
2. & Woman & 0 & $0 \%$ \\
& Total & 43 & $100 \%$ \\
\hline
\end{tabular}

Source: Questionnaire Collection, 2017

Table 2 revealed that the number of male respondents was 43 people or $100 \%$, and the female respondents were also 0 people or $0 \%$. Based on the data in Table 4.2, it appeared that all respondents were male, this is because work in agriculture is more suitable for men because it requires stronger energy, body resistance is also stronger than feminists. With technological advances in coffee processing, necessarily feminism can be seen in the processing and marketing of coffee beans. It should not only be men who are working in the field of coffee farming but also needs the involvement of women, especially in terms of making a decision, because businesses that are only dominated by men usually cannot run well, because they need assistance as a correction in making the right decision. Because men usually use prioritize rational while women use prioritize emotionally. Combination in making a decision between men and women, namely between rational and emotional funds, will usually get better decisions.

3) Educational Level

Based on the research results, a description of the educational level of the respondents can be seen in Table 3 below:

Table 3

Characteristics of Respondents Based on Educational Level

\begin{tabular}{llll}
\hline No & The latest educational level & Number of respondents (people) & Percentage (\%) \\
\hline 1. & Elementary School & 11 & $25,58 \%$ \\
2. & Junior High School & 12 & $27,91 \%$ \\
3. & Senior High School/Vocational & 17 & $39,53 \%$ \\
& School & 3 & $6,98 \%$ \\
4. & Bachelor & 43 & $100 \%$ \\
\hline
\end{tabular}

Source: Questionnaire Collection, 2017

Table 3 showed that the respondents have Elementary school educational level as many as 11 people or $25.58 \%$, junior high school educational level as many as 12 people or $27.91 \%$, Senior High School/Vocational School as many as 17 people or 39.53\%, Bachelor degree at about 3 people or $698 \%$. Based on Table 4.3, it

Karyati, N. K. ., Windia, W. ., Susrusa, B. ., \& Adiputra, G. S. . (2020). The independence level of farmers in Subak Abian Tri Guna Karya on processing and marketing agricultural products. International Journal of Life Sciences, 4(3), 16-30. https://doi.org/10.29332/ijls.v4n3.472 
appeared that most of the respondents were in the high school educational level of $39.53 \%$. This data showed that coffee farmers have the same knowledge as high school graduates. High school graduates usually have competency levels including: 1) behave following their religious teachings and following the adolescent's development; 2) being confident and responsible for their work; 3) being respectful to the diversity; 4) Demonstrates the ability to think logically, critically, creatively and innovatively in taking a decision; 5) Demonstrate the ability to develop learning culture for self-empowerment; 5) Demonstrate competitive attitude and sportsmanship to get the best results; 6) Utilizing land and environment productively and responsibly; (7) Participating in social life, 8) Communicating orally and in writing effectively and politely; 9) Appreciate differences in opinion and have empathy for others. Based on the competence possessed by teenage farmers, it is known that coffee farmers in Subak Abian Tri Guna Karya, Kintamani, Bangli can be developed towards creativity, productivity, critical thinking, independently and in collaboration with coffee farmers and other people related to the coffee plantation, and have the ability to communicate and build good cooperation networks.

4) Farmer Behavior

The results of research conducted can obtain an overview of the characteristics of farmer behavior which was shown in Table 4 below:

Table 4

Characteristics of Farmer Behavior

\begin{tabular}{llll}
\hline No & Characteristics of Individual Farmers & Score & Category \\
\hline 1 & Knowledge & 3,39 & Good \\
2 & Skill & 4,29 & Very Good \\
3 & Attittude & 4,13 & Good \\
\hline
\end{tabular}

Source: Questionnaire Collection, 2017

The elements of farmer behavior in Table 4.4 above consisted of three things, namely, knowledge, skills, and attitudes. This showed that the characteristics of respondents assessed from individual farmers in implementing their skill have a score of 4.29 , which means that individual farmers have very good skill. But seen from the individual farming knowledge, it had a score of 3.39 , which means that the knowledge of farmers was below their skill. The skill that has been mastered was very good because they learned directly from the environment. Meanwhile, they have limited knowledge of modern agriculture.

\section{Independence of farmers}

The independence of farmers in this study can be seen from emotional independence, economic independence, and intellectual independence as shown in Table 5 below:

Table 5

Independence of Farmer

\begin{tabular}{llll}
\hline No & Independence of Farmer & Score & Category \\
\hline 1 & Economy & 4.35 & Very Good \\
2 & Intellectual & 4.08 & Good \\
3 & Emotional & 3.75 & Good \\
& Average & 4,06 & Very Good \\
\hline
\end{tabular}

Based on Table 5 above, the independence of farmers when viewed from an economic point of view materially had a score of 4.35 which was a very good category score. While the intellectual independence of farmers was in a good category with a score of 4.08, and emotionally, the value achieved with a score of 3.75 was classified as good. The results of the scores obtained above indicate that economically the independence of farmers who join in Tri Guna Karya Subak Abian community was very good. As the goal of the community empowerment 
process belonging to the Tri Guna Karya Subak Abian community was farmer independence. As shown in Table 4.5 that the independence of farmers from an economic point of view was classified as very good. This showed that economically farmers in Catur Village were very strong, this can be seen from the houses they have, their vehicles, the level of education and even usually having recreation outside the region.

Economic independence is also followed by intellectual independence, with a good economy, which can be used to support education towards a higher level of education, so that it can automatically support the intellectuals of Catur Village. Besides, emotional independence was categorized as good, showing that the emotional independence of farmers was very well-honed. When the farmers were economically independent and well-established, by having high intellectual wisdom, they will be emotionally controlled, so that the welfare of the farmers can be achieved.

Talking about the independence of farmers, three things need to be considered namely, 1) independence from an economic perspective, usually indicated by having sufficient savings; 2) can learn independently; 3 ) able to make the right decisions. If seen at Table 5 above, showed that farmers who were members of Subak Abian Tri Guna Karya Group, Kintamani District, Bangli Regency were economically independent, and farmers already have sufficient savings because of the sales of coffee, also, because coffee is High-value agricultural products. Another independence in terms of learning showed that farmers who have savings in the form of money did not want to update themselves because they were already in the comfort zone with the money they have. This is of course against entrepreneurship. If this is accompanied by a more willingness to learn, farmers can certainly earn more than before.

The farmers' habit of being in the comfort zone is accompanied by low decision-taking, and this means that farmers were very dependent on other people, whether dependent on the leader, kelian subak, the existing coffee traders. So, to increase farmer independence, what can be done was to use savings economically to update themselves through education. Asking farmers to continue learning was certainly impossible, but farmers must learn through non-formal education in the family or through extension. If we pay attention to the data obtained, it indicated that education and learning activities were not good, even though coffee products are global products. The government must take action so that farmers willing to learn for themselves. If this is done, the capital owned will be much more profitable, especially in current conditions.

Catur Village has the excellent potential of natural resources, even towards geographical indications. These excellent conditions such as soil, temperature, light, landscapes are very suitable for coffee plants. This natural capital makes Catur Village got a geographic indication certificate. The coffee that is owned by this Catur village has a different taste from coffee in other regions.

\subsection{Independence level of Subak Abian Tri Guna Karya Farmers, Kintamani District, Bangli Regency in processing and marketing of products}

The farmer empowerment program that has been regulated by the government is the cause of the farmer's dependence on this empowerment program. Empowerment of economic community includes four aspects, namely: strengthening ownership of production factors, strengthening control of distribution and marketing, strengthening the community to get adequate wages/payment, and strengthening the community to obtain information, knowledge, and skills, which must be done from two sides simultaneously, both from the community and from the policy (Hutomo, 2000).

The empowerment level of Subak Abian Tri Guna Karya, Kintamani District, Bangli Regency in processing and marketing agricultural products certainly has an impact on farmer independence. According to Steinberg in Ginintasi (2009), independence can be seen from 3 aspects, namely:

1) Emotional autonomy, namely the independence of each group and freeing oneself from dependence on meeting the basic needs of group farming.

2) Behavior autonomy, which is independence in free behavior to act or act independently without depending on the group.

3) Value autonomy, namely the independence of a person to make decisions and make choices that adhere to individual principles.

Karyati, N. K. ., Windia, W. ., Susrusa, B. ., \& Adiputra, G. S. . (2020). The independence level of farmers in Subak Abian Tri Guna Karya on processing and marketing agricultural products. International Journal of Life Sciences, 4(3), 16-30. https://doi.org/10.29332/ijls.v4n3.472 
Factors related to the empowerment of Subak Abian Tri Guna Karya, Kintamani District, Bangli Regency in developing capital business certainly have an impact on the level of farmer independence. The indicators used as a reference in achieving the level of independence are as follows:

1) Characteristics of individual farmers consisting of:

a) Knowledge

b) Skills

c) Attitude

2) Development capitals consisting of

a) Natural capital

b) Physical capital

c) HR capital

d) Social capital

3) The independence of farmers includes:

a) Economy

b) Intellectual

c) Emotional

Measurement explanation of each variable in empowerment level of Subak Abian as follows:

1) Characteristics of individual farmers as measured by using the level of farmer knowledge, skills possessed by farmers and farmer attitudes in the group indicated that the numbers achieved were $0.611,0.867,0.841$, respectively. Based on the results of the calculation of these figures, it showed that the knowledge of farmers reaches a figure of 0.611 . This means that the knowledge possessed by farmers is also be able to increase independence doing in agriculture field. Furthermore, in terms of farmer skills, the score obtained is 0.867 . This means that the farming skills in groups have the highest score, compared to the knowledge and attitudes possessed. This showed that if farmers want to be successful and independent, the most important thing that must be possessed is skill and resilience. A farmer group with the skills possessed are diligent and tenacious, the level of independence will be achieved.

On the other hand, if the farmers' knowledge is getting better, usually the ability to manage their business can be done more professionally. From the results of statistical calculations, it showed that knowledge had value of 3.39, skills have score of 4.29. This means that in addition to their very good skills, it is also important for farmers to have good knowledge, because with knowledge, perhaps farmers can carry out agricultural activities through agribusiness management.

Through management, they will be able to establish their own business in selling production facilities, as well as collector traders, and other businesses that can be carried out in groups. Agribusiness management will be able to encourage farmers to face various competitions. This competition is mainly in strengthening the independence of farmers through increasing the function of the group as a production unit so that there is an improvement benefit from their farming activities which cannot be separated from various training in the application of technological innovations.

Based on the results of statistical tests on farmers' attitudes, which gave a value of 0.841 , it means that farmers have a positive attitude (especially in accepting change). The success of farmers in farming that is carried out cannot be separated from the attitude they have in doing business. If this role is implemented optimally, commodity development will also be achieved optimally. This will be a good effort to increase farmers' independence.

2) Development capitals consist of natural capital, physical capital, human resources, and social capital One indicator of the farmer group independence is usually seen from the member's participation to access capital from existing financial institutions. On the other hand, the group must realize that the group's dependence on government programs, such as the provision of facilities, technology, information, and direct funding assistance, is only temporary. Therefore, we need an effort that leads to social motivation to increase group empowerment to make groups independent and able to solve their problems in groups.

These natural resources can provide many benefits if managed properly, on the other hand, they can cause disaster if exploited excessively. Natural resources according to Manihuruk (2017), consist of: 
1) Natural Capital

a) Land, land can be used for agriculture, a good business location will make it easier for groups to do agricultural marketing. The value of land from year to year continues to increase, therefore farmers need to protect their agricultural land so that it can provide benefits for future generations.

b) Water, water is a vital resource. Because water can be used for all types of purposes such as for electricity generation (PLTA), fisheries, irrigation, tourism, and so on.

c) Forests, many natural resources can be obtained from forests, such as various flora and fauna. Other benefits are as a source of oxygen production, a source of wood raw materials, and as water absorption.

d) Mining Materials. Gold, petroleum, iron, tin, gems, nickel, and so on, are the results of mining. These materials have many benefits for humans. For example, petroleum has benefits as vehicle fuel, as well as other mining materials.

e) The energy contained in nature includes sunlight, wind, ocean waves, nuclear, geothermal, etc. These energies, if properly exploited, will provide many benefits to humans.

2) Physical capital

At the beginning of its development, the capital was only viewed from the physical aspect, which means that the capital of a company is something that can be seen, touched, and used to support the company's operational activities. The notion of capital which is only physically oriented then develops, where capital is not only interpreted as a tangible (physical) thing that belongs to the company, but it is further related to the value, and also the ability to take advantage of everything that is owned by the own capital goods.

It is not only physical capital and financial capital that plays a role in creating value in a company. With the emergence of the informational age and globalization, companies can't again generate a sustainable competitive advantage only by applying new technology to their physical capital appropriately or simply by properly implementing asset and liability management. The ability of a company to mobilize and exploit its intangible assets is much more decisive than investing and managing tangible assets (Ekowati, 2014).

3) Human Resources (HR)

This human resource occupies a more important position than other resources. Humans have perfection when compared to other creatures, this is because humans have reason and mind. By using their minds maximally, humans can create various advances and benefits for society.

4) Social capital

Social capital is everything related to cooperation in society to achieve a better life goal. One element of social capital needed in a group is the nature and attitude of mutual trust. Trust is a very important asset to build partnerships (cooperation) with outsiders. Cooperation based on trust will occur if it is based on honesty, fairness, openness, mutual care, mutual respect, and mutual assistance among group members.

Farmers have always known and held honesty or trustworthiness as a traditional value, which without them realize, it is one of the social capital concepts that is always used as a reference for choosing a figure or leader, especially in rural communities (Pratisthita, 2014). Every farmer group that is in the community always wants to realize its independence. Therefore, the group must have economic capital in the form of money that can be used to buy the facilities and production tools needed by the group concerned. Because with all the capital owned by the group, independence will be achieved, so that the welfare of the group will continue to be improved.

\subsection{Discussion on the level of farmers independence in Subak Abian Tri Guna Karya, Kintamani District, Bangli Regency in processing and marketing of agricultural products}

The involvement of farmers in farmer groups is important as a means of interacting, communicating, learning from each other, and exchanging experiences between farmers, and farmers will get benefit from these activities in supporting their agricultural businesses. But the involvement of farmers in farmer groups is low, indicating that farmers cannot get benefit from the existence of farmer groups. On the other hand, Sinaga et al. (2016), argued that farmer groups play an important role in agricultural development.

Karyati, N. K. ., Windia, W. ., Susrusa, B. ., \& Adiputra, G. S. . (2020). The independence level of farmers in Subak Abian Tri Guna Karya on processing and marketing agricultural products. International Journal of Life Sciences, 4(3), 16-30. https://doi.org/10.29332/ijls.v4n3.472 
The independence of farmers in Subak Abian Tri Guna Karya, Kintamani District, Bangli Regency can be achieved if the farmers who are members of the group are willing and obedient to their belief in the advantages of farmers if they join the group. So there is an individual element that stands out in achieving independence level. As the results of the study showed that the characteristics of individual farmers measured by using the level of farmers' knowledge, skills possessed by farmers, and farmers' attitudes in groups indicate that the knowledge possessed by farmers is also able to increase independence in doing agriculture business. Likewise, the skills in group farming showed that if farmers want to be successful and independent, the most important thing that must be possessed is skill and resilience.

In developing the capacity of farmers by using the system and as grouping which is as an effort to increase competitiveness to face globalization and free trade era. By farmers grouping, it will be easier to move the agribusiness system in rural areas. If the farmers have an organizational spirit then build a business together through groups. Then the combined knowledge will provide greater opportunity for the success of agricultural development. As a group, farmers in the current openness era have found it easier to access markets.

If viewed from the participation of members in accessing government programs, such as provision of means and facilities, technology, information, and direct temporary assistance, it is still important to continue to do so; this will certainly reduce the financial capital that must be spent by farmers. Although at the beginning of its development, physical capital and financial capital were very important to have, along the journey, where capital is not only interpreted as something tangible (physical) but more about the value that human resources as farmers must-have. This value is the capital of farmers in groups to increase independence. Human resources always occupy a more important position than other resources. Because humans have reason and mind, they can create various advances and benefits for society.

As research conducted in several countries such as Japan, with all its limitations encourages optimizing its human resources. Now, Japan has been able to show as a country that is very advanced in technology and economy likewise Singapore and other countries. The progress made by developed countries also prioritizes honesty and discipline. Whatever the position and situation of the person, honesty, and discipline are needed. The existing advanced countries, such as America, Singapore, Japan, on average their citizens have a high level of discipline. With discipline, the targets that have been planned will always be achieved.

Farmers' group is also holding important beliefs. Trust is an important asset to build partnerships (cooperation) with outsiders. Cooperation based on trust will occur if it is based on honesty, fairness, openness, mutual care, mutual respect, and mutual assistance among group members. If all of the above capital is owned by the group, independence will be achieved, and automatically the group's welfare will continue to increase.

Almost all research conducted by other parties states that independence is influenced by the genes or descent of parents, parenting styles, the education system in schools, and the education system in society. With good cooperation among group members it is also believed to be able to increase the independence of farmers. This research is also in line with research conducted by Marliati et al. (2010). Where in her research it was stated that the low level of independence of agribusiness farmers was caused by (a) low group capacity, (b) networking capacity, (c) low levels of formal education and non-formal education of farmers. The education factor (capacity building) is the main factor determining the level of farmers' independence.

The results of other studies conducted by Ruhimat (2014) are also in line with this study. In his research, it was stated that the level of ability and dynamism of farmers in community forest management were factors that had direct effect on the level of farmers' independence. Central and local governments are advised to strengthen forest education, training, and extension institutions in the regions. This research is in line with research conducted by Sinaga \& Yulida (2016), which stated that the level of independence of self-help pattern rubber farmers in making cultivation and post-harvest decisions is high, this is evidenced by the influence of the level of formal education, non-formal education, farming experience, farming motivation, farmer income, and farmer group support, availability of facilities and production infrastructure, financial institution support, extension agency support, information source support, and government policy support. Individuals must continue to learn to be independent dealing with various environmental situations, so that individuals will eventually be able to think and act independently (Tjandraningtyas, 2004).

Self-reliance for entrepreneurship is very highly influenced by personality or by entrepreneurial individuals, thus making entrepreneurs successful. This research is also in line with the theory of 
independence developed by Steinberg (1995), namely the ability of individuals or the ability to manage ourselves will increase independence.

\section{Conclusion}

Based on the results of the analysis and discussion in the previous chapter, it can be concluded that the level of farmers independence in Subak Abian Tri Guna Karya, Kintamani District, Bangli Regency in processing and marketing agricultural products is classified as very good, which is characterized by intellectual independence.

Suggestions

a) Members of Subak Abian Tri Guna Karya, Kintamani District, Bangli Regency should be able to improve their knowledge and skills, so they can be more independent in processing and marketing agricultural products.

b) Subak Abian Tri Guna Karya, Kintamani District, Bangli Regency should maintain harmony and honesty among group members, so that the trust will continue to increase, and ultimately be able to increase the independence of members and groups.

Acknowledgments

We are grateful to two anonymous reviewers for their valuable comments on the earlier version of this paper.

Karyati, N. K. ., Windia, W. ., Susrusa, B. ., \& Adiputra, G. S. . (2020). The independence level of farmers in Subak Abian Tri Guna Karya on processing and marketing agricultural products. International Journal of Life Sciences, 4(3), 16-30. https://doi.org/10.29332/ijls.v4n3.472 


\section{References}

Burger, P. C., \& Cann, C. W. (1995). Post-purchase strategy: a key to successful industrial marketing and customer satisfaction. Industrial Marketing Management,24(2), 91-98. https://doi.org/10.1016/00198501(94)00036-V

Desmita, 2014. Psikologi Perkembangan Peserta Didik. Bandung: Remaja Rosdakarya.

Ekowati. (2014). Pengaruh Modal Fisik, Modal Finansial, Dan Modal Intelektual Terhadap Kinerja Perusahaan Pada Perusahaan Manufaktur Di Bursa Efek Indonesia.

Elina, R.S., Asfi M., \& David K. (2012). Modal Sosial Dan Keberhasilan Pelaksanaan Program Pengembangan Usaha Agribisnis Pedesaan Di Kabupaten Manokwari. Universitas Brawijaya Malang. SEPA, 8(2), 51 - 182. ISSN : 1829-9946.

Fukuyama, F., \& Amrullah, M. H. (1999). The End of History and The Last Man: Kemenangan Kapitalisme dan Demokrasi Liberal. Penerbit Qalam.

Ghozali, Imam. 2011. Aplikasi Analisis Multivariate Dengan Program SPSS. Semarang: Badan Penerbit Universitas Diponegoro.

Ginintasi, R. (2009). Kontribusi pola pengasuhan orang tua terhadap perkembangan kemandirian dan kreativitas anak. Makalah. Bandung: FIP-Universitas Pendidikan Indonesia.

Hair Jr, J. F., Sarstedt, M., Hopkins, L., \& Kuppelwieser, V. G. (2014). Partial least squares structural equation modeling (PLS-SEM). European business review.

Hutomo, M. Y. (2000). Pemberdayaan masyarakat dalam bidang ekonomi: Tinjauan teoritik dan implementasi. Bappenas, Jakarta.

Hutton, J. G. (1996). Integrated marketing communications and the evolution of marketing thought. Journal of Business Research, 37(3), 155-162. https://doi.org/10.1016/S0148-2963(96)00065-3

Kuncoro, M. (2007). Metode Kuantitatif Teori dan Aplikasi untuk Bisnis dan Aplikasi. UPP STIM YKPN Yogyakarta.

Manihuruk, J. (2017). Reklamasi final secara hokum.

Marliati, S., Asngari, P. S., Tjitropranoto, P., \& Saefuddin, A. (2010, July). Faktor-Faktor Yang Berpengaruh Terhadap Kemandirian Petani Tanaman Pangan Beragribisnis Di Kabupaten Kampar, Provinsi Riau. In Forum Pascasarjana (Vol. 33, No. 3, pp. 221-228).

Mawardi, M. J. (2007). Peranan Social Capital dalam Pemberdayaan Masyarakat. Jurnal Pengembangan Masyarakat Islam, 3(2), 5-14.

Molden, D., Oweis, T., Steduto, P., Bindraban, P., Hanjra, M. A., \& Kijne, J. (2010). Improving agricultural water productivity: Between optimism and caution. Agricultural Water Management, 97(4), 528-535. https://doi.org/10.1016/j.agwat.2009.03.023

Mubyarto. (1994). Pengantar Ekonomi Pertanian. Jakarta: Bagian Penerbit LP3ES.

Muliarta, I. N. (2016). The evaluation of implementation of integrated farming system program and the reality of increasing farmers income in Bali. International research journal of engineering, IT \& scientific research, 2(7), 108-114.

Nurhayati, E. (2018). Psikologi pendidikan inovatif (Vol. 2). Pustaka Pelajar.

Permana, C. H. A., \& Purnomo, D. (2014). Evaluasi Program Pemberdayaan Masyarakat: Suatu Analisis Dalam Perspektif Pemberdayaan Masyarakat. Cakrawala, 3(1).

Pranadji, T. (2017). Penguatan kelembagaan gotong royong dalam perspektif sosio budaya bangsa: Suatu upaya revitalisasi adat istiadat dalam penyelenggaraan pemerintahan. In Forum Penelitian Agro Ekonomi (Vol. 27, No. 1, pp. 61-72).

Pratisthita, R. N. (2014). Peran modal sosial dalam menunjang dinamika kelompok peternak sapi perah (studi Kasus di Kelompok 3 TPK Pulosari Pangalengan). Jurnal Ilmu Ternak Universitas Padjadjaran, 14(1).

Ruhimat, I. S. (2014). Faktor-Faktor untuk Peningkatan Kemandirian Petani dalam Pengelolaan Hutan Rakyat: Studi Kasus di Desa Ranggang, Kabupaten Tanah Laut, Kalimantan Selatan. Jurnal Penelitian Sosial dan Ekonomi Kehutanan, 11(3), 29127.

Schaller, N. (1993). The concept of agricultural sustainability. Agriculture, ecosystems \& environment, 46(1-4), 89-97. https://doi.org/10.1016/0167-8809(93)90016-I

Sharpley, A. N., Gburek, W. J., Folmar, G. J., \& Pionke, H. B. (1999). Sources of phosphorus exported from an agricultural watershed in Pennsylvania. Agricultural water management,41(2), 77-89. https://doi.org/10.1016/S0378-3774(99)00018-9 
Sinaga \& White. (1980). Problem of Institutional Agriculture in Indonesia. Jakarta: Universitas Indonesia.

Sinaga, G., \& Yulida, R. (2016). Tingkat Kemandirian Petani Karet Pola Swadaya dalam Pengambilan Keputusan USAhatani di Desa Kuntu Kecamatan Kampar Kiri Kabupaten Kampar (Doctoral dissertation, Riau University).

Sinaga, P. H., Rosnita, R., \& Yulida, R. (2016). Dinamika Kelompoktani Kelapa Sawit Pola Swadaya di Kecamatan Bagan Sinembah Kabupaten Rokan Hilir (Doctoral dissertation, Riau University).

Steinberg, L. (1995). Adolescene Sanfrancisco.

Suhartini, R., Halim, A., Khambali, I., \& Basyid, A. (2005). Model-model pemberdayaan masyarakat. Yogyakarta: Pustaka Pesantren.

Sulistiyani, A. T. (2004). Kemitraan dan model-model pemberdayaan. Gava Media.

Sumodiningrat, G. (1999). Pemberdayaan masyarakat dan jaring pengaman sosial. Gramedia Pusataka Utama.

Sunyoto, U. (2004). Pembangunan dan Pemberdayaan Masyarakat. Yogyakarta:Pustaka Pelajar.

Tjandraningtyas, J. (2004). Anakku Mandiri: Peran Orang Tua Terhadap Perkembangan Kemandirian Anak.

Walker, B. A., \& Olson, J. C. (1991). Means-end chains: Connecting products with self. Journal of business research, 22(2), 111-118. https://doi.org/10.1016/0148-2963(91)90045-Y

Karyati, N. K. ., Windia, W. ., Susrusa, B. ., \& Adiputra, G. S. . (2020). The independence level of farmers in Subak Abian Tri Guna Karya on processing and marketing agricultural products. International Journal of Life Sciences, 4(3), 16-30. https://doi.org/10.29332/ijls.v4n3.472 


\section{Biography of Authors}

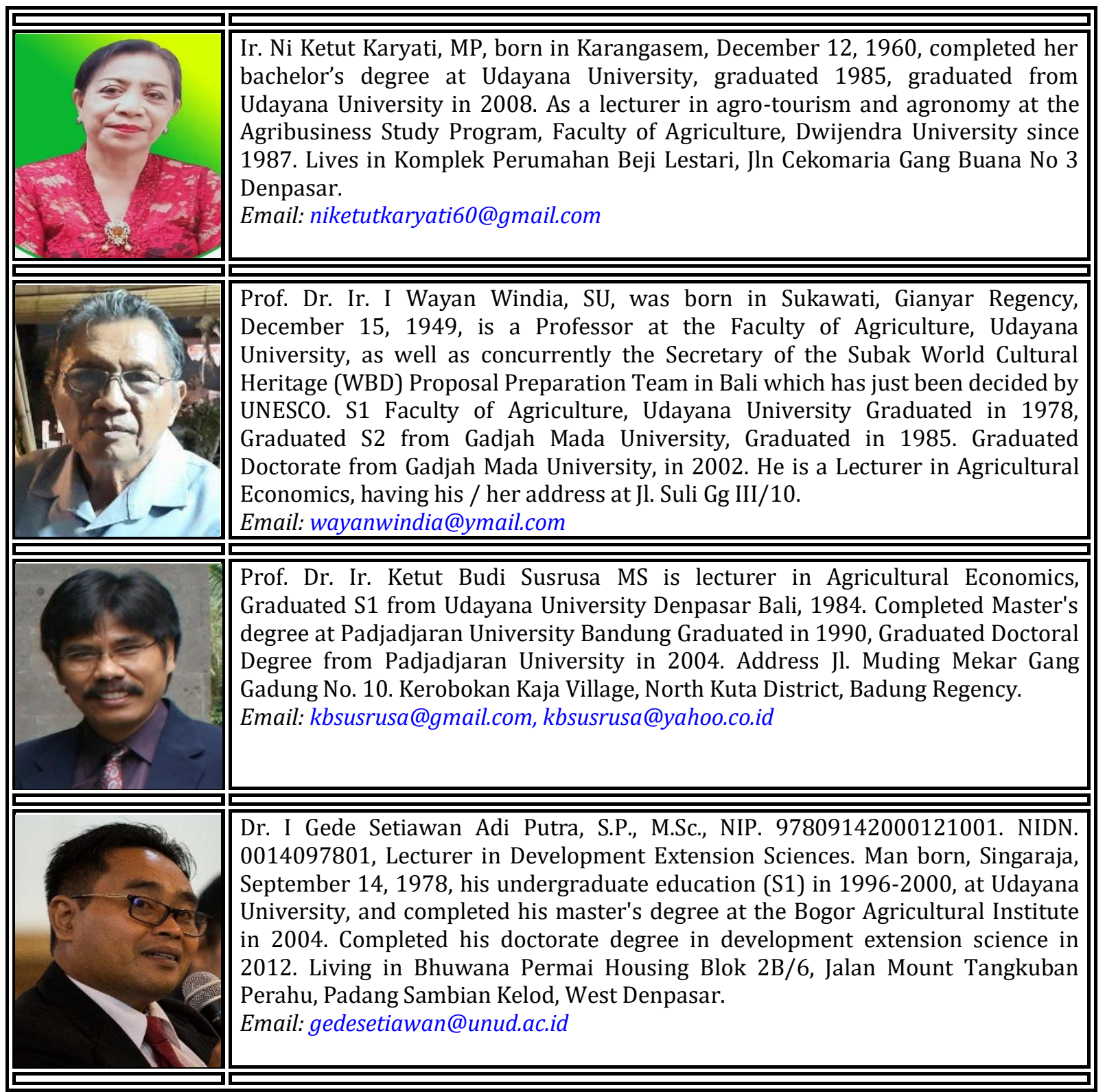

